\title{
Biological soil crusts of Arctic Svalbard and of Livingston Island, Antarctica
}

\author{
Laura Williams ${ }^{1} \cdot$ Nadine Borchhardt $^{2}$ - Claudia Colesie ${ }^{1} \cdot$ Christel Baum $^{3}$. \\ Karin Komsic-Buchmann ${ }^{4}$ Martin Rippin ${ }^{4} \cdot$ Burkhard Becker $^{4} \cdot$ Ulf Karsten $^{2}$ • \\ Burkhard Büdel ${ }^{1}$
}

Received: 2 September 2015/Revised: 19 February 2016/ Accepted: 13 May 2016/Published online: 6 June 2016 (c) The Author(s) 2016. This article is published with open access at Springerlink.com

\begin{abstract}
Biological soil crusts (BSCs) occur in arid and semi-arid regions worldwide including the Polar Regions. They are important ecosystem engineers, and their composition and areal coverage should be understood before assessing key current functional questions such as their role in biogeochemical nutrient cycles and possible climate change scenarios. Our aim was to investigate the variability of BSCs from Arctic Svalbard and the Antarctic Island, Livingston, using vegetation surveys based on classification by functional group. An additional aim was to describe the structure of BSCs and represent a classification system that can be used in future studies to provide a fast and efficient way to define vegetation type and areal coverage. Firstly, this study demonstrates huge areas occupied by BSCs in Arctic Svalbard, with up to $90 \%$ of soil surface covered, dominated by bryophytes and cyanobacteria, and showing an unexpectedly high variability in many areas. Livingston Island has lower percentage coverage, up to $55 \%$, but is dominated by lichens. Our findings show that both Polar Regions have varied BSC coverage, within the sites and between them, especially considering their harsh climates and latitudinal positions. Secondly, we have classified the BSCs of both areas into a system that describes the dominant functional groups and local
\end{abstract}

Laura Williams

Williams@rhrk.uni-kl.de

1 Plant Ecology and Systematics, University of Kaiserslautern, Kaiserslautern, Germany

2 Applied Ecology and Phycology, University of Rostock, Rostock, Germany

3 Soil Science, University of Rostock, Rostock, Germany

4 Cologne Biocenter, University of Cologne, Cologne, Germany geography, creating a simple scheme that allows easy identification of the prevailing vegetation type. Our results represent the first contribution to the description of BSCs based on their functional group composition in Polar Regions.

Keywords Biological soil crusts (BSCs) - Vegetation . Functional groups $\cdot$ Svalbard $\cdot$ Livingston Island

\section{Introduction}

Biological soil crusts (BSCs) are a complex amalgamation of organisms and soil particles that form on the surface and in the top millimetres of soil; cyanobacteria, microalgae, microfungi, bacteria, bryophytes, liverworts, and lichens all contribute, in various compositions, to the structure and function of these micro-ecosystems. They can be the only vegetation cover in arid and semi-arid landscapes, can improve soil stability, increase resistance to erosion, and improve colonisation potential of higher plants (Belnap and Lange 2003). The ecosystem services provided by BSCs are of high importance where higher primary producer influences are low, as in Polar Regions. Nitrogen and carbon are limiting factors to polar plant growth (Yoshitake et al. 2007); however, nitrogen fixed by cyanobacteria of BSCs provides sufficient levels to support the associated mosses and vascular plants (Dickson 2000). BSCs are known to accumulate organic matter which benefits the often carbon-limited soil biota (Belnap 2003), and forms the trophic base on which heterotrophic organisms depend (Elster et al. 1999).

The initial stages of BSC development, for example after glacier retreat, create a habitat suitable for further cryptogamic and plant establishment by increasing the 
nutrient and moisture content of the soil and are therefore essential to succession processes within Polar ecosystems (Bliss and Gold 1999; de los Rios et al. 2011).

Few studies have so far focused on the BSCs of Antarctica, and of those that have, continental Antarctica has been the focus (Green and Broady 2001; Colesie et al. 2013, 2014; Büdel et al. 2014). The climatic and latitudinal gradients from Continental Antarctica to the Antarctic Peninsula and Maritime Antarctic are huge, and therefore, inferring information regarding the composition of BSCs based on these previous studies is of limited value. However, plant communities, which include the two vascular plants of Antarctica (Lewis Smith and Poncet 1987), have been often described for the Maritime Antarctic (Gimingham and Lewis Smith 1970; Lewis Smith 1972, 1984, 1996; Ochyra 1998; Ochyra and Lewis Smith 1999; Olech 2002). Lindsay (1971) compared Livingston floristics with King George Island, finding strong similarities in species and community composition, and Sancho et al. (1999) describes the bryophyte and lichen flora of Livingston's South Bay, reporting strong similarities with the rest of Livingston. Although species lists, community composition, and gradients have been frequently discussed, there is no mention of BSCs, only the organisms that make up BSCs as part of described communities. Svalbard in comparison has been the focus of some BSC research, being a much more accessible location and hence the vegetation has been more widely described. Johansen et al. (2012) produced the most recent large-scale vegetation map of Svalbard using satellite imagery. This data set clearly depicts the inhospitable interior of Svalbard's mountainous, Arctic desert and categorises the vegetation communities along the coastal regions, but not to a landscape scale or from a BSC perspective. Cooper (2011) and Cooper et al. (2004) describe species assemblages on a landscape scale but focusing on higher plants and seedling emergence, which in some instances can be related to the presence of cyanobacterial crust. Jónsdóttir (2005) explores the heterogeneity and complexity of Svalbard's terrestrial ecosystems, and Prach et al. $(2010 ; 2012)$ describes vegetation variability on small spatial scales, including species lists of mosses and lichens, and community composition from a higher plant perspective. As with the Maritime Antarctic, research literature exists describing the plants, bryophytes, and lichen communities of Svalbard (e.g. Elvebakk 1994; Vanderpuye et al. 2002; Øvstedal et al. 2011), also in the wake of receding glaciers (Hodkinson et al. 2003). Pushkareva and Elster (2013) describe the diversity of cyanobacteria and microalgae of Petunia Bay, Svalbard, in cryptogamic soil crusts, classifying them into three types: black-brown, brown, and grey-brown, depending on the diversity of cyanobacteria and microalgae identified. However, the majority of studies considering BSCs focus on a particular attribute, such as their contribution to the carbon cycle (Yoshitake et al. 2010) or metal accumulation due to air pollution (Wojtuń et al. 2013), and do not describe the communities themselves, their composition, or areal coverage.

BSCs found in alpine regions may be the most similar to those in high latitudes due to comparable climatic conditions and glacial history compared to BSCs found in warm desert/semi-desert areas. The BSCs of Hohe Tauern National park in the Austrian Alps have been described by Peer et al. (2010), Büdel et al. (2014), and Zheng et al. (2014). These studies show a high coverage of BSCs in this area (up to $60 \%$ ), being especially dominated by cyanobacteria.

The soil types found in Polar Regions may play an important role in the structure of the BSCs. Patterned ground which occurs in polar and high alpine areas due to frost cracking and cryoturbation has been shown to influence soil properties, such as nutrient and material sorting, in Svalbard (Szymański et al. 2015). The constant soil movement may also interrupt BSC succession as organisms cannot become established. Physical weathering, as opposed to chemical weathering, by freeze thaw action has also been shown to control the soil formation of Livingston Island (Navas et al. 2008; Haus et al. 2015). The young soils of Polar Regions combined with low chemical weathering processes due to the severe climate result in low soil nutrient contents. BSCs, commonly found on such soils, are typically found to be low in nutrients (Belnap 2002; Belnap and Lange 2003); however, their biological activities do introduce nutrients and organic matter accumulation contributes to soil formations.

Characterisation and description of vegetation communities are fundamental to ecology and the understanding of ecosystem dynamics. Depiction of a community based on species composition is extremely useful, although when comparing BSCs from a worldwide perspective it may give a completely different impression than other methods. Functional group composition on the other hand can show similarities and differences in BSCs structure, which species composition may not so obviously indicate. Although a cyanobacterial crust on opposite sides of the world may constitute different species assemblages, their functions within the ecosystem may be, for all intents and purposes, the same. Eldridge and Rosentreter (1999) first provided this framework to classify BSCs on a morphological group level. The advantage of using such an approach is that fewer expertises are needed than identifying organisms on a species level. Büdel et al. (2009) utilised this approach along a 2000-km transect through South Africa and southern Namibia, using a classification of BSCs based on different taxonomic compositions. The authors distinguish seven general crust types: light cyanobacteria crust, 
cyanobacteria crust, cyanobacteria crust with cyanolichens, cyanobacteria crusts with cyanolichens and/or green algal lichens, crusts with bryophytes, hypolithic crusts, and the unique Namib Desert lichen fields.

The present investigation aims to introduce and classify BSCs from Arctic Svalbard and the Antarctic Island, Livingston. The various vegetation types are categorised for both regions to create a simple reference system to distinguish between types. A functional group comparison within and between Polar Regions improves the understanding of the variability, composition, and areal coverage of BSCs in areas that have thus far not been determined as such.

\section{Materials and methods}

\section{Study sites}

\section{Svalbard}

The Arctic region is represented by two localities, Spitsbergen, Svalbard: Ny-Ålesund $\quad\left(78^{\circ} 55^{\prime} 26.33^{\prime \prime} \mathrm{N}\right.$, $\left.11^{\circ} 55^{\prime} 23.84^{\prime \prime} \mathrm{E}\right)$ and Longyearbyen $\left(78^{\circ} 13^{\prime} 10.18^{\prime \prime} \mathrm{N}\right.$, $15^{\circ} 39^{\prime} 7.19^{\prime \prime} \mathrm{E}$ ) (Fig. 1a). Ny-Ålesund is an international research platform on the Brøgger peninsula at the coast of Kongsfjorden, and Longyearbyen is the largest settlement on Svalbard and found in the Nordenskiöld Land on the coast of Adventfjorden. Svalbard is a Norwegian archipelago located in the North Atlantic and Arctic Oceans. This group of islands ranges from $74^{\circ}$ to $81^{\circ}$ north latitude and from $10^{\circ}$ to $35^{\circ}$ east longitude. Svalbard is characterised by relatively mild climatic conditions compared to regions at the same latitudes because of the West Spitsbergen Current, which flows along the West coast of Spitsbergen and transports warm Atlantic water masses into the Arctic Ocean. The mean temperature of Ny-Ålesund is $8{ }^{\circ} \mathrm{C}$ and of Longyearbyen $5{ }^{\circ} \mathrm{C}$ in summer and of both localities $-14{ }^{\circ} \mathrm{C}$ in winter. However, longer cold periods $(-20$ to $-35^{\circ} \mathrm{C}$ ) are possible. Based on the temperature, three different zones exist: the mid Arctic tundra zone $\left(5-7^{\circ} \mathrm{C}\right)$, the northern Arctic tundra zone $\left(3-5{ }^{\circ} \mathrm{C}\right)$, and the Arctic polar desert $\left(<3{ }^{\circ} \mathrm{C}\right)$. The annual precipitation averages $471 \mathrm{~mm}$ in Ny-Ålesund and $205 \mathrm{~mm}$ in Longyearbyen, with 70 and $65 \%$, respectively, falling between October and May, when snow cover is usually complete (based on data from the Norwegian Meteorological Institute).. The bedrock of Svalbard is predominantly carbonate rock (Tredow 1977). The surface soil of the A-horizon $(0-5 \mathrm{~cm})$ has a predominantly sandy texture, and mean values of $\mathrm{pH}$ $\left(\mathrm{H}_{2} \mathrm{O}\right)$ are 6.2-7.9. Electrical conductivity is 43-69 $\mu \mathrm{S}$ $\mathrm{cm}^{-1}$, organic carbon content is $0.12-0.70 \%$, total nitrogen content is $0.11-0.14 \%$, and bioavailable (Mehlich- extractable) phosphorus content is $3-31 \mathrm{mg} \mathrm{kg}^{-1}$ in the area of test sites (Mann et al. 1986).

Svalbard is covered by less than $10 \%$ of vegetation, and current information includes ca. 170 vascular plants, ca. 350 mosses (Bengtsson 1999), and ca. 600 lichen species (Elvebakk and Hertel 1997).

\section{Livingston Island}

The Antarctic research area is centred around the Juan Carlos I base $\left(62^{\circ} 39^{\prime} 46.00^{\prime \prime} \mathrm{S} 60^{\circ} 23^{\prime} 20.00^{\prime \prime} \mathrm{W}\right)$ (Fig. 1b), which is located in the South Bay of Livingston Island, Antarctica. Livingston Island belongs to the South Shetland archipelago in the Southern Ocean which is situated near the Antarctic Peninsula. The archipelago is separated from the Antarctic Peninsula by Bransfield Strait and from South America by the Drake Passage. It ranges from $61^{\circ}$ to $63^{\circ}$ south latitude and from $54^{\circ}$ to $63^{\circ}$ west longitude.

The South Shetland archipelago and the Antarctic Peninsula, respectively, are the most northerly parts of Antarctica; therefore, it has the mildest climate within this continent. Based on the effect of the Antarctic Circumpolar Current, the temperatures are relatively low. Detailed meteorological data are available from the Juan Carlos I base (Bañón 1989) and for Byers Plateau in the South of Livingston (Bañón et al. 2013). Mean annual temperatures are $-2.8^{\circ} \mathrm{C}$ with summer mean temperatures above freezing, and maximum mean temperature is $4.3^{\circ} \mathrm{C}$. Mean annual precipitation is $444.5 \mathrm{~mm}$, with $75 \%$ falling in summer and autumn. Both climate stations provide correlative data, but show that the western side of the Island is colder and windier. The bedrock of Livingston Island is a low-grade metamorphic turbidite sequence with volcanic to volcanoclastic rocks, intruded by igneous bodies (Arche et al. 1992; Moura et al. 2012). The surface soil of the A-horizon $(0-5 \mathrm{~cm})$ of the test sites was characterised by sandy loam as the dominating texture class, mean values of $\mathrm{pH} \quad\left(\mathrm{H}_{2} \mathrm{O}\right)$ are 7.3-7.7, electrical conductivity is $28-33 \mu \mathrm{S} \mathrm{cm}^{-1}$, total organic carbon content is $0.39-0.56 \%$, total nitrogen contents are about 0.06-0.10\% (Otero et al. 2013), and bioavailable (Mehlich-extractable) phosphorus contents are $7-40 \mathrm{mg} \mathrm{kg}^{-1}$.

Antarctica as a whole has only two native flowering plant species, the grass Deschampsia antarctica Desv. and the Antarctic pearlwort Colobanthus quitensis (Kunth) Bartl. Numbers of lichen (110) and bryophyte (50) species were reported from the vicinity of Juan Carlos I base in Livingston by Sancho et al. (1999), the study covered a relatively small area; however, the phytogeographic structure of South Bay flora was considered to be typical of the Maritime Antarctic flora that was described by Castello and Nimis (1997). In addition, of the 211 lichen taxa identified from the South Shetland Islands (Øvstedal and 

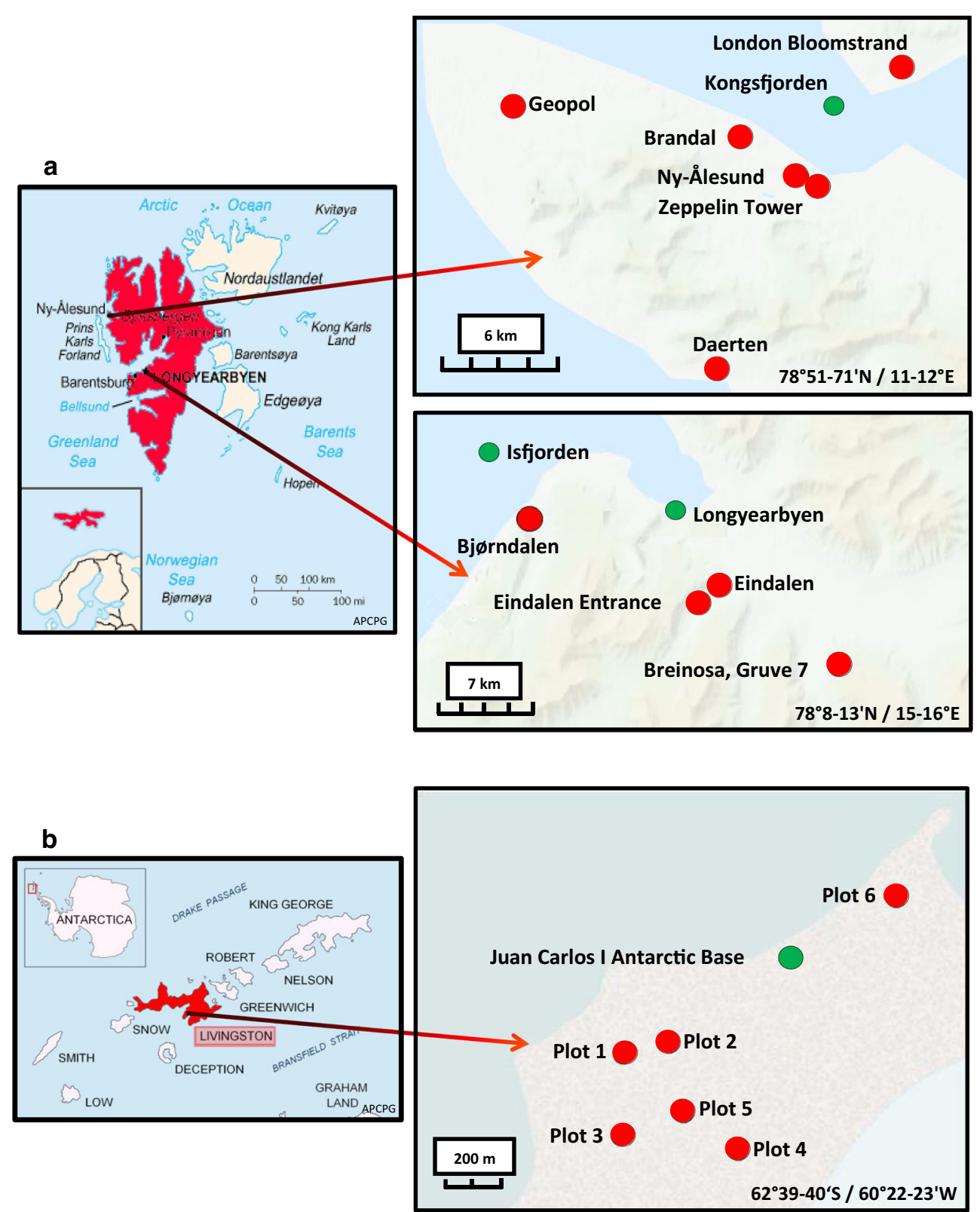

Fig. 1 a Svalbard field sites centred around Ny-Ålesund and Longyearbyen, Spitsbergen. The red markers denote the vegetation plots. b Livingston Island in relation to Continental and Maritime

Lewis Smith 2001), nearly half were also identified from South Bay, Livingston, regardless of the small area.

\section{Vegetation surveys}

In August 2014, the vegetation surveys were carried out in Svalbard and in February 2015 in Livingston. In a $25 \times 25 \mathrm{~m}\left(=625 \mathrm{~m}^{2}\right)$ area of homogeneous vegetation, plots were established for the vegetation surveys. The different plot areas were selected in order to cover the variability occurring within the wider region. The point
Antarctica, and Plots 1-6 of the vegetation surveys around Juan Carlos I Antarctic Base. LAT/LONG encompasses all plots per site

intercept method (Levy and Madden 1933), a commonly used method in determining vegetation coverage of BSCs, was applied. Twenty-five subplots of $25 \times 25 \mathrm{~cm}$ $\left(=625 \mathrm{~cm}^{2}\right)$ were randomly selected within each established plot, and the functional groups in each subplot were determined ( 25 point measurements). In total, 625 point measurements per plot were undertaken. We differentiated between the following BSC functional groups: green algal crust; cyanobacterial crust; cyanolichen; chlorolichen; and bryophyte (see Table 1 and Fig. 2 for commonly associated species), and also the other biotic and abiotic groups 
Table 1 BSC functional groups

\begin{tabular}{|c|c|}
\hline $\begin{array}{l}\text { Functional } \\
\text { group }\end{array}$ & Ecosystem functions \\
\hline Cyanobacteria & $\begin{array}{l}\text { Photosynthesis and } \mathrm{N} \text {-fixation, photosynthesis also at very high water contents, needs liquid water for net photosynthesis, soil } \\
\text { stabiliser via EPS production }\end{array}$ \\
\hline Green algae & $\begin{array}{l}\text { Photosynthesis with very low water content, depression of net photosynthesis at water supra-saturation, in the case of } \\
\text { filamentous types also soil stabilisers }\end{array}$ \\
\hline Chlorolichens & $\begin{array}{l}\text { Soil stabiliser and effective preventer of soil erosion, photosynthesis and production of secondary metabolites that can be } \\
\text { leached into the ground, some can be activated by high air humidity alone }\end{array}$ \\
\hline Cyanolichens & Net photosynthesis at very high water content, leaching of N-rich metabolites, soil stabiliser \\
\hline Bryophytes & $\begin{array}{l}\text { Effective soil stabilisers by deep penetration of rhizoids and protonemata, form an upper canopy of the BSCs, effectively } \\
\text { photosynthesise even at very high thallus water contents via their elongated architecture }\end{array}$ \\
\hline
\end{tabular}

associated with BSCs: higher plants; litter; abiotic crust; open soil, stones and gravel. Each plot, 6 in Livingston (Fig. 1b) and a total of 10 in Svalbard, 6 and 4 in $\mathrm{Ny-}$ Ålesund and Longyearbyen, respectively (Fig. 1a), contained 25 subplots (75 in one location), which was assessed to be sufficient to achieve accurate, representative community composition, and areal coverage.

Functional group percentage coverage was calculated from the surveys for each plot, similarity indices were computed using EstimateS (Version 9, R. K. Colwell, http://purl.oclc.org/estimates), and the Morisita Horn index was used to visualise the data by multidimensional scaling (MDS) in Statistica V.13 using program defined parameters. A stress value below 0.15 was considered a good fit to the data (Dugard et al. 2010).

\section{Results}

The diversity and extreme variability of BSCs that were initially observed in Svalbard led us to devise a new system of vegetation characterisation to easily distinguish between the types and create consistency. The characterisation is based on easily observable factors, such as the dominant features or vegetation type. Figure 3 represents the characterisation of Svalbard, and the vegetation type is also consistent with altitude, as can be observed on the schematic beginning at sea level and rising to the steep active scree of the mountains (Johansen et al. 2012). The coastal areas are home to huge areas of BSC and are a massive contrast to the inhospitable Arctic desert of Svalbard's interior.

\section{Svalbard vegetation types identified (Fig. 3)}

I Steep active scree: no BSCs or any other vegetation.

II Steep inactive scree: patchy BSCs, different compositions.

III Gentle brash: dominated by lichens.
IV Coastal plains:

IVa Closed BSC coverage encompasses huge areas (cyanobacteria, algae, lichens, and mosses).

$\mathrm{IVb}$ Closed moss carpets, boggy vegetation, related to the availability of meltwater.

IVc Permafrost and polygon soils (sorted circles), BSCs consistently on the sorted fine material (cyanobacteria, algae, lichens).

The initial types of BSCs identified are consistent between both polar sites, characterised by the mountainous, rocky habitat, and little vegetation. In Livingston, an obvious altitudinal gradient is also evident as depicted in the schematic (Fig. 4); increased abundance of lichens, mosses, and higher plants, in various proportions, is consistent with the availability of water. However, although the immediate comparison is evident, the scales are on a completely different level. Livingston's landscape is characterised by rocky hillocks (Fig. 4 Type IVa) gradually rising to around $400 \mathrm{~m}$ a.s.1. This is in strong contrast to the mountains which begin from a few hundred metres of Svalbard's coast line. The hillocks are abundant in the fruticose lichen Usnea antarctica Du Rietz, and the bases of these formations, where water collects, are abundant in bryophytes.

\section{Livingston vegetation types identified (Fig. 4)}

I Steep active scree: no BSCs or any other vegetation.

II Steep inactive scree: patchy BSCs in different compositions.

III Hillocks: Lichens, especially fruticose, increased BSC coverage, fewer bryophytes.

IV Hillocks: Lichens, especially fruticose, BSCs, bryophytes, grasses.

IVa Increased abundance of bryophytes.

$\mathrm{IVb}$ Less BSCs, probably initiation stages; water runoff evident.

V Closed moss carpets, boggy vegetation, related to the availability of water. 

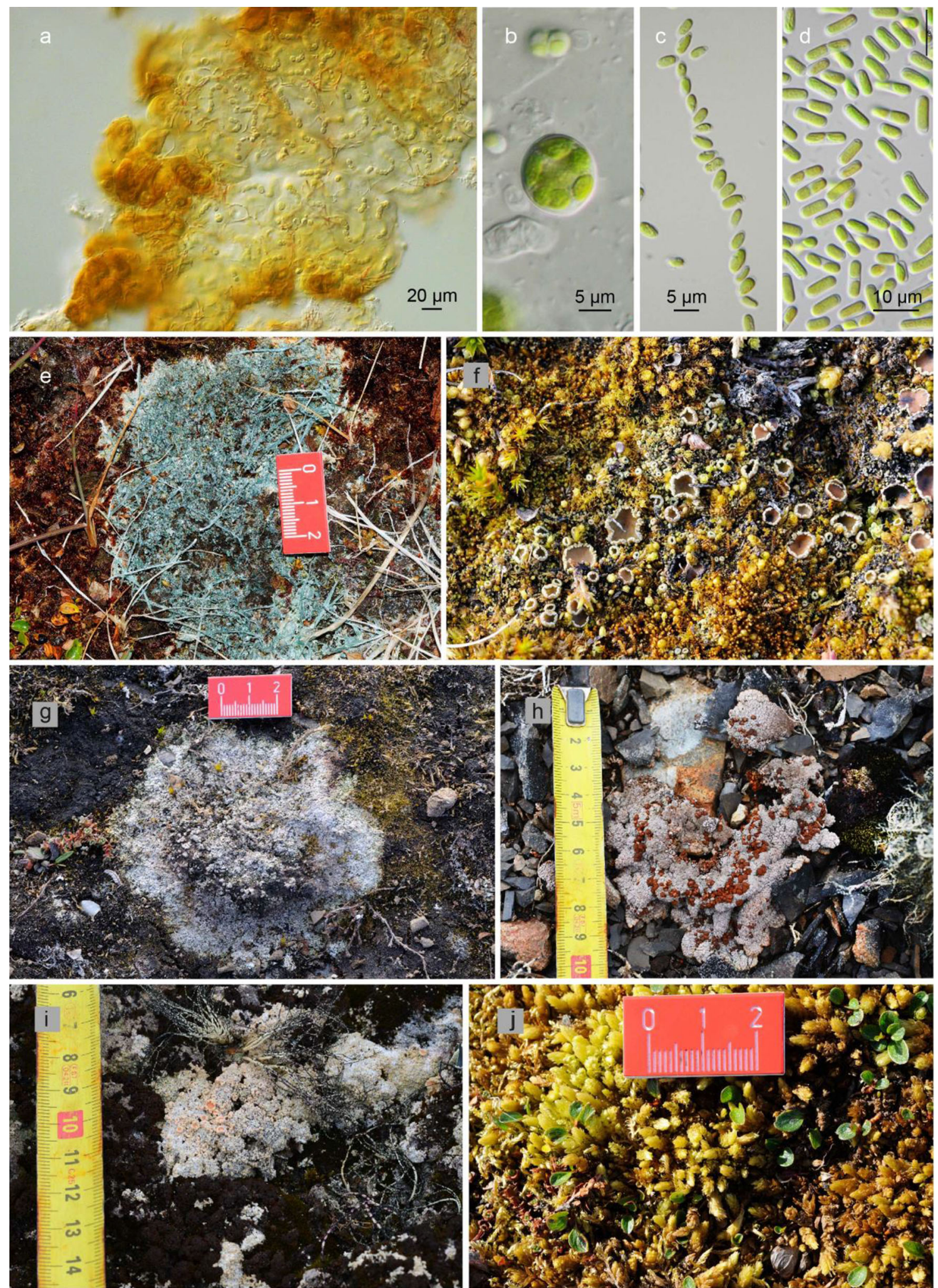
4Fig. 2 Typical Arctic-Antarctic cryptogams: a Nostoc cf. commune colony, very common in Svalbard BSC, often heavily infected by fungal hyphae. b Pseudochloris pseudopolychloris, a green alga common in BSC of Ny Ålesund and Longyearbyen. c Pseudococcomyxa simples, a green alga common in BSC of Ny Ålesund and Longyearbyen. d Stichococcus bacilaris, a green alga common in BSC of Ny Ålesund and Longyearbyen. e The saprophytic mold Trichoderma sp., a common fungus on BSC mosses and lichens, common in Ny Ålesund and Longyearbyen regions. f Psoroma, characteristic lichen for BSC on deeper soil in all regions. $\mathbf{g}$ Lepraria cf. neglecta, chlorolichen common on BSC of deeper soils in both Svalbard regions. h Placopsis contortuplicata, Livingston, Antarctica. i Ochrolechia frigida, Livingston, Antarctica. j Orthothecium sp., a common moss of BSC on deeper soil from both Svalbard regions

\section{Svalbard BSC composition}

Average BSC coverage is $50 \%$, but the variability in coverage is striking and ranges between 18 and $90 \%$ in the different locations. The sites around Ny-Ålesund also show the high variability of BSCs habitats, from the rocky Geopol site with very little vegetation, to the moss and cyanobacterial crust-dominated sites of Zeppelin Tower at Ny-Ålesund, to the moss-dominated site of Brandal (Fig. 5a). Comparing the locations of sites to the BSCs coverage corresponds to the schematic (Fig. 3) designed

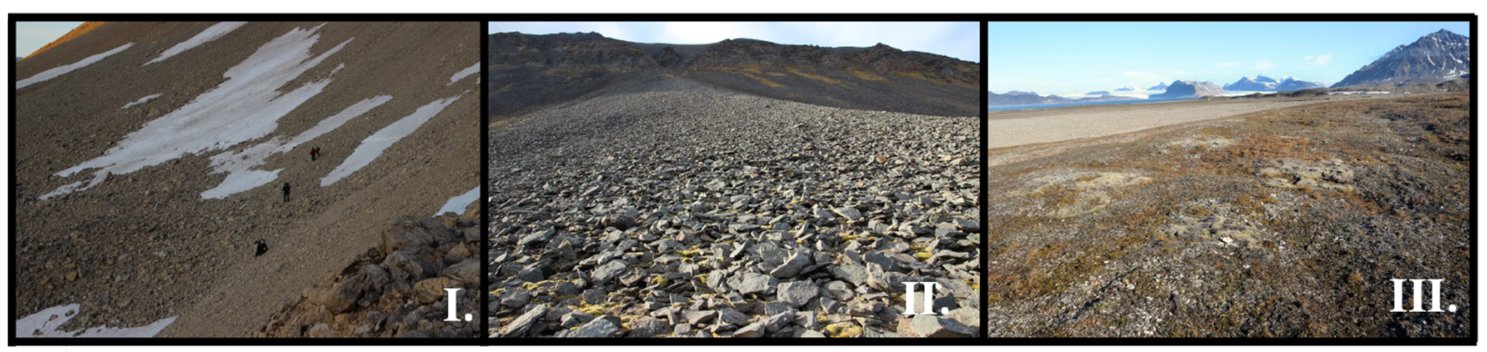

(c) N. Borchhardt

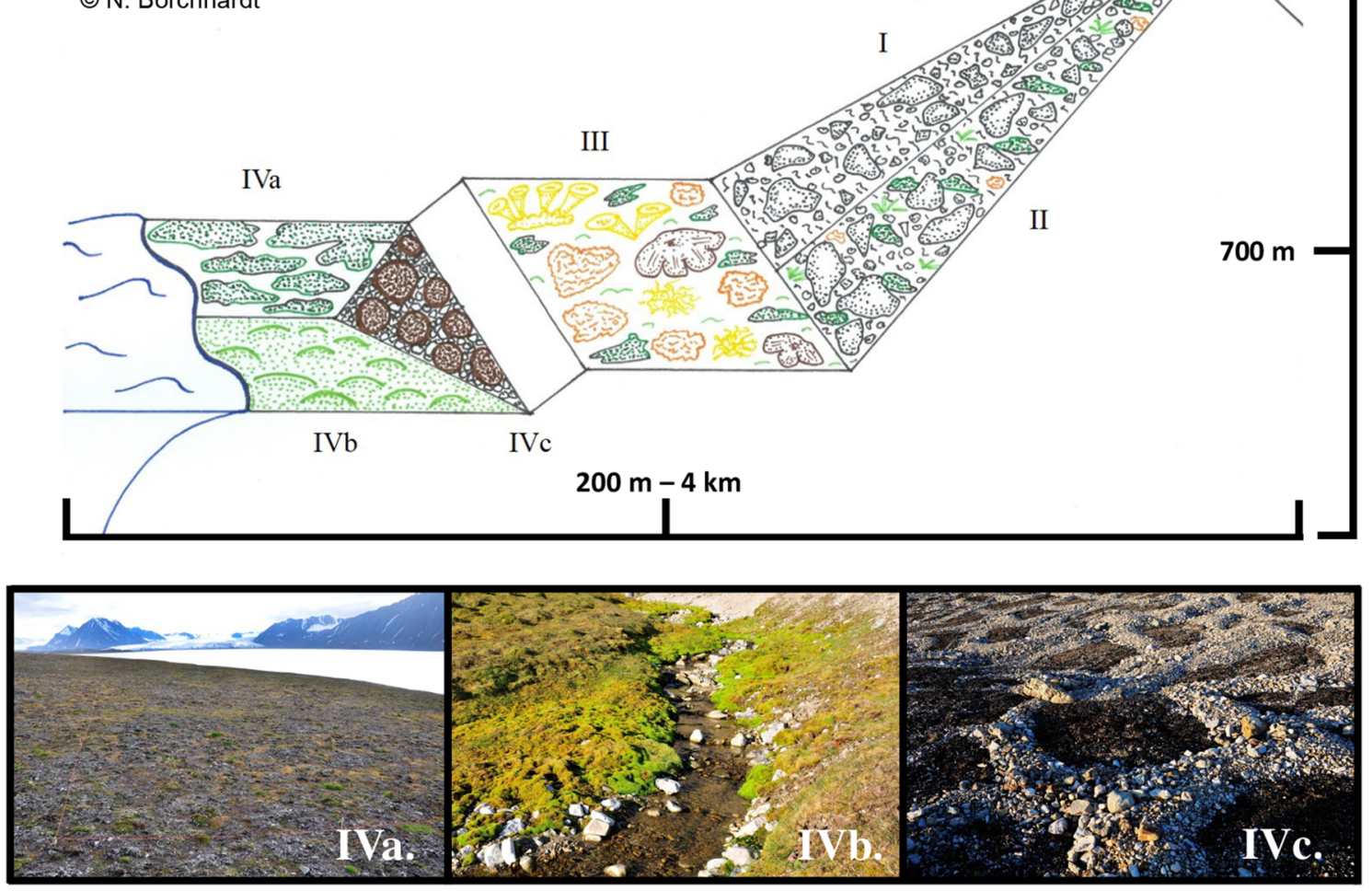

Fig. 3 Vegetation characterisation of Svalbard. Schematic represents the altitudinal gradient and distribution of the BSCs. Types and Photographs: I Steep active scree: No BSCs or any other vegetation. II Steep inactive scree: patchy BSCs, different compositions. III
Gentle brash: dominated by lichens. IV Coastal plains: IVa Closed BSC coverage encompasses huge areas. IVb Closed moss carpets, boggy vegetation. IVc Permafrost polygon soils (sorted circles), BSCs consistently on sorted, fine material 


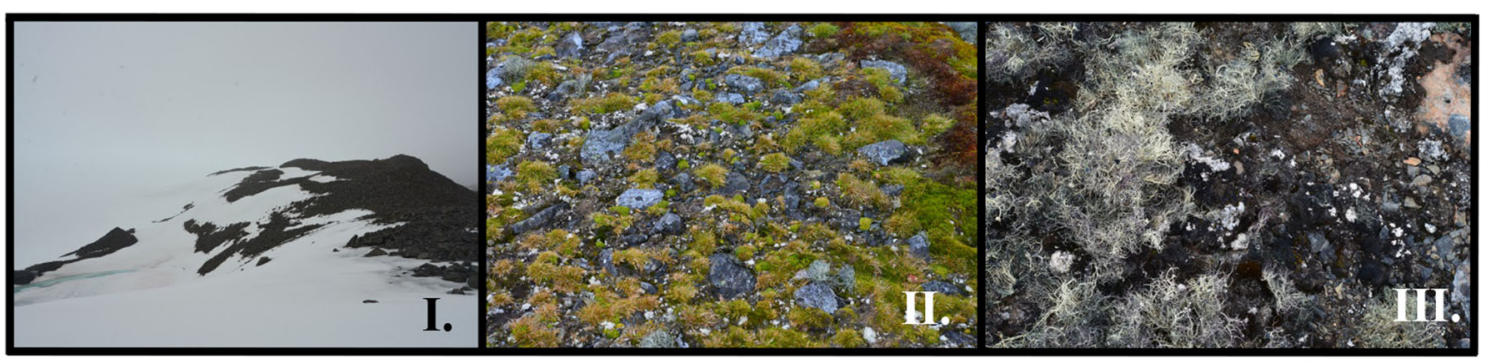

(c) N. Borchhardt
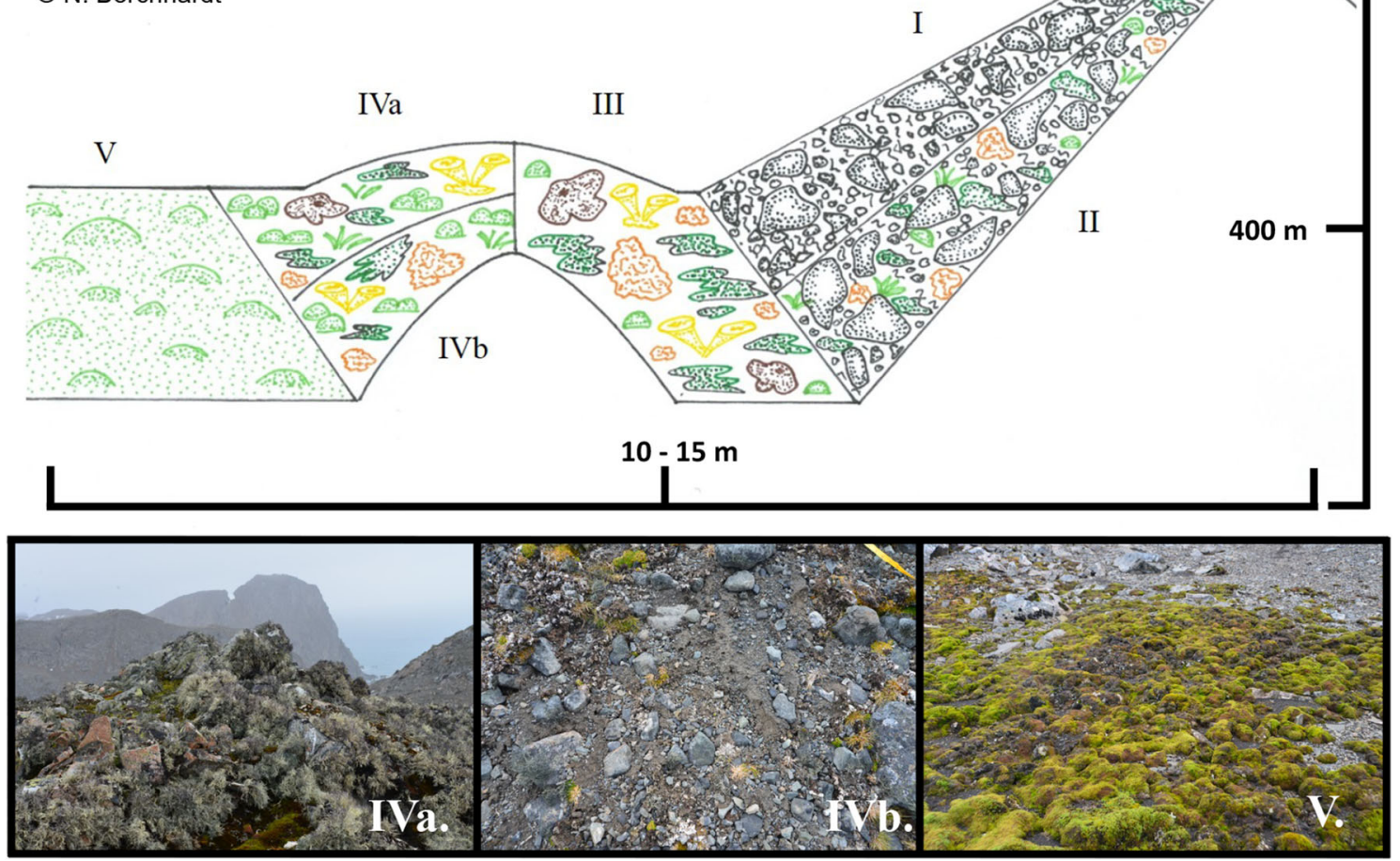

Fig. 4 Vegetation characterisation of Livingston Island. Schematic represents the altitudinal gradient and distribution of the BSCs. Types and photographs: I Steep active scree: no BSCs or any other vegetation. II Steep inactive scree: patchy BSCs, different compositions. III Hills: Lichens, increased BSCs, fewer mosses. IV Hills: Lichens, BSCs, bryophytes, grasses. IVa Increased abundance of bryophytes. IVb Less BSCs maybe initiation stages. V Closed moss carpets, boggy vegetation for Svalbard, and the sites closer to the coast show greater proportions of higher plants, bryophytes, and lichens compared to such sites as Geopol and Breinosa Gruve 7 (Fig. 5b) which are further inland and therefore in the mountainous regions and dominated by skeletal soils. This soil type is comparable to the soil of Livingston. Fig. 6 shows that these sites are more similar to those of Livingston than to the deeper soil sites of Svalbard. The MDS also shows that Bjørndalen, Brandal, Ny-Ålesund, and Eindalen plots have greater similarity than those from Eindalen Entrance or Zeppelin Tower and Daerten and thus suggesting that the BSC composition is not dependent on the geographical location, but most probably on soil and/or microclimatic conditions.

\section{Livingston BSC composition}

Due to time constraints, the vegetation surveys in Livingston covered a much smaller area than in Svalbard. The differences in vegetation coverage are between 20 and $55 \%$, which is not as high as Svalbard, and the average BSC coverage is just over $30 \%$. Chlorolichens are the dominant functional group, and higher plants make up a very small percentage of coverage in only plot 6 (Fig. 6). One out of 6 plots showed vegetation coverage higher than $50 \%$, with open soil, gravel and stones being the dominant feature of the landscape.

Plot 4 exhibited the lowest percentage of BSC coverage (Fig. 6) and is the furthest site from the coast (Fig. 1b). This is comparable to the BSC coverage in Svalbard, with 
Fig. 5 Percentage cover of BSCs, biotic, and abiotic functional groups in a NyÅlesund, b Longyearbyen, Svalbard
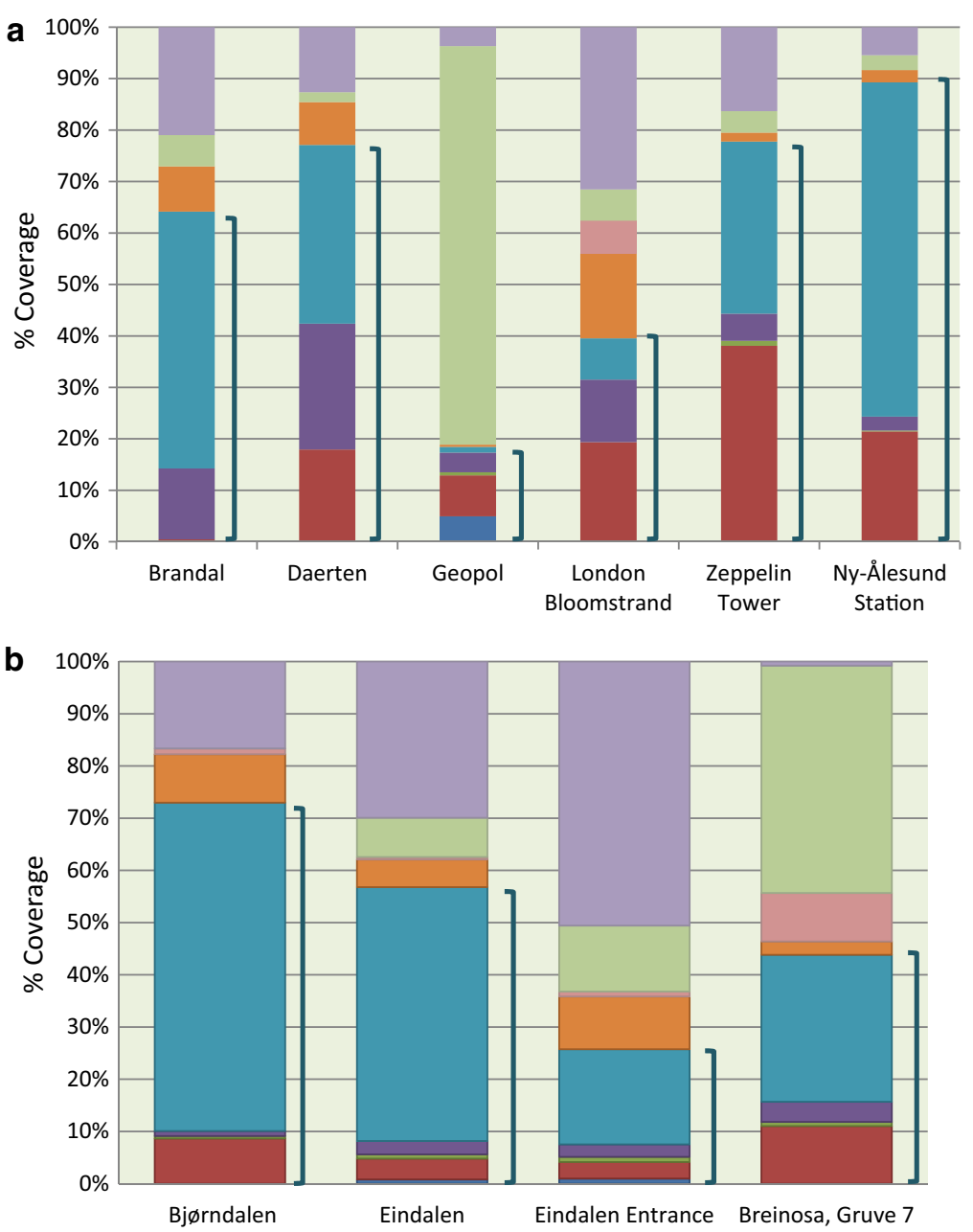

BSC functional groups

\begin{tabular}{|c|c|c|c|}
\hline green algae crust & a cyanobacterial crust $\square$ cyanolichen & chlorolichen & $\square$ moss \\
\hline litter & open soil, sand & stones, gravel & nigher plant \\
\hline
\end{tabular}

coastal areas being more suitable for BSC development. The MDS (Fig. 7), in addition to the bar charts, indicates that the Livingston plots are similar to each other compared to the plots in Svalbard. Therefore, functional group coverage in Livingston BSCs is more uniform.

\section{Assigning the vegetation plots to a vegetation type}

Using the vegetation types described in the schematics, the vegetation data demonstrating percentage coverage of functional groups, plot photographs, and locations, the different plots in both regions were assigned to a dominant vegetation type (Table 2). Whenever possible, an area of homogenous vegetation was selected when conducting the surveys; however, due to the nature of the terrain, this was not always possible, especially in Livingston Island where the terrain is markedly composed of rocky hillocks. For example, Plot 2 of Livingston Island has two dominant vegetation types assigned; this denotes the transition from the hillock-type vegetation of type IV into the bryophytedominated base of type $\mathrm{V}$. The schematics provide a simple classification system that generally applies to the vegetation composition found in the respective sites and plots. However, heterogeneity cannot be avoided, especially when investigating a micro-ecosystem, such as a BSC, influenced by microclimate and local landscape, on a relatively large scale. Therefore, the assigned vegetation type does not always apply to the entire vegetation plot and hence represents at least the dominance of one (or two) types.

\section{Discussion}

Much of the BSC distribution in Svalbard can be attributed to its geology, as shown in the schematic (Fig. 3). The steep scree-covered mountain sides are unsuitable for the 


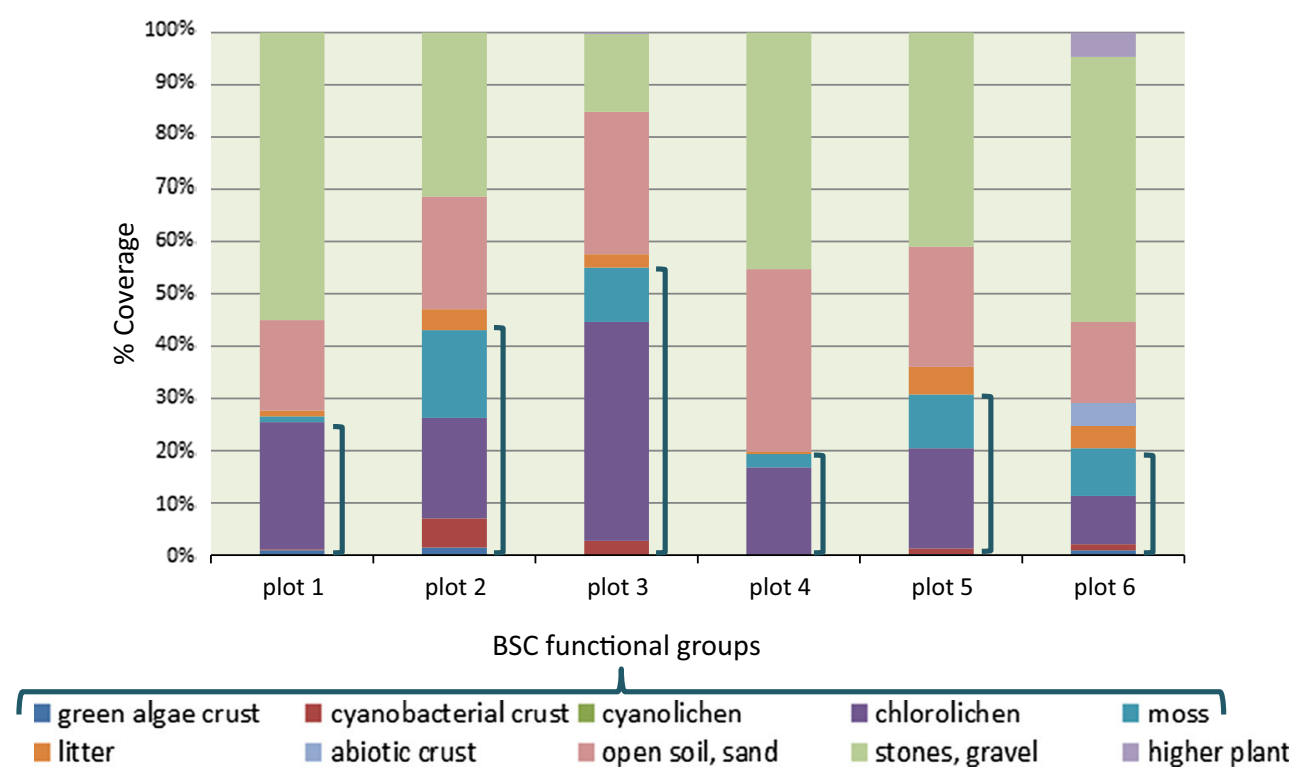

Fig. 6 Percentage cover of BSCs, biotic, and abiotic functional groups, Livingston Island, Antarctic

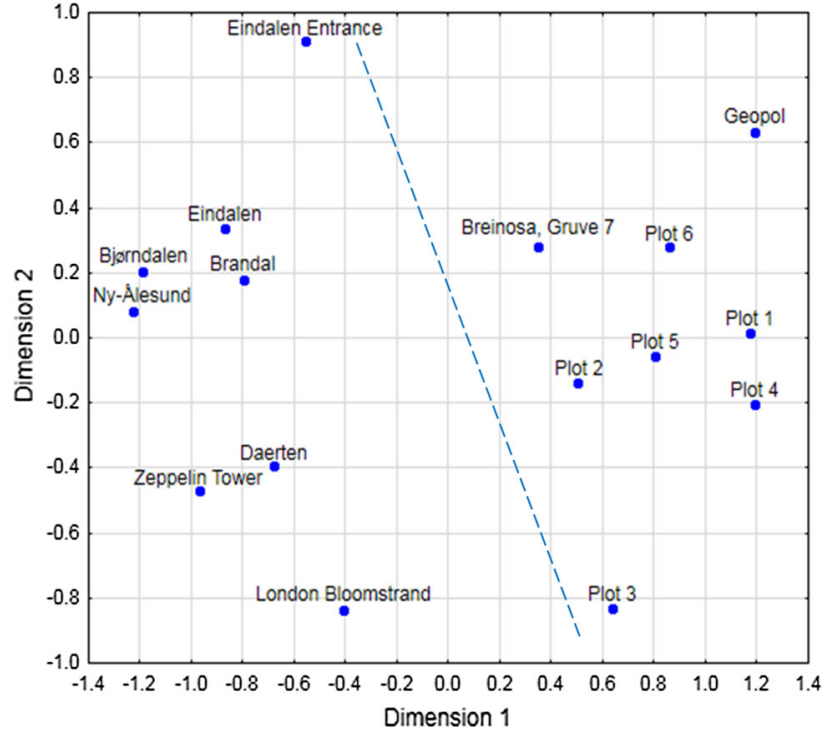

Fig. 7 Multidimensional scaling (MDS) based on Morisita Horn similarity Index of functional groups. (Stress value $<0.102$ ) The blue line represents the separation of plots based on skeletal and deeper soils

formation of vast stretches of BSCs; however, towards the coast, the inhospitable environment gradually recedes and water availability increases, in the most part due to snow melt and hence water flow towards the coast.

Livingston receives higher levels of precipitation during austral summer than Svalbard in northern summer, and therefore, the vegetation is not so reliant on meltwater. This allows the hillocks, which would not be accessible to meltwater accumulation, to be abundant in fruticose lichens- and bryophyte-dominated BSCs. Due to lower summer temperatures in Livingston reducing snow melt and the absence of Svalbard's mountain ranges, meltwater is likely to be less important to the function of the ecosystem.

With up to $90 \%$ of soil dominated by BSCs around NyÅlesund station, this can be considered one of the highest levels of coverage so far known. Across European sites, BSCs were found to cover between 40 and $60 \%$ (Büdel et al. 2014); in Southern Africa, 20-30\% was common although rarely, up to $70 \%$ was recorded (Büdel et al. 2009); and in the Mojave Desert, $50 \%$ cover was located in only the most developed areas (Pietrasiak et al. 2011). Considering the harsh environment, short growing season, and low summer rainfall levels, this highly developed crust coverage is remarkable, especially when $\mathrm{Ny}$-Ålesund is compared to other areas, which can be considered to be more hospitable to BSC organisms due to much longer growing seasons and higher levels of precipitation. The high and consistent availability of water at the beginning of the growing season may be attributable to these surprisingly high levels of BSCs coverage. What these areas lack in precipitation they gain from the large amounts of snow melt consistently running from the mountains through these areas (Johansen et al. 2012) dominated by huge swathes of BSCs. The high coverage of cyanobacterial crusts, (demonstrated in this study and also by Turicchia et al. 2005 and Pushkareva and Elster 2013) also supports this concept; the BSC composition is comparable to the Alpine BSCs of the Alps where annual precipitation is around 5 times greater (Büdel et al. 2014). Cyanobacteria need liquid water to photosynthesise (Lange et al. 1986), and therefore in an area where precipitation falls mainly as 
Table 2 Vegetation plots were assigned to a dominant vegetation type as described in the schematics by comparing plot locations, photographs, and percentage coverage data

\begin{tabular}{|c|c|c|c|c|}
\hline \multirow[t]{2}{*}{ Vegetation plot } & \multirow[t]{2}{*}{ Soil } & \multirow[t]{2}{*}{ Latitude/longitude } & \multicolumn{2}{|c|}{ Dominant vegetation type } \\
\hline & & & Code & Description \\
\hline \multicolumn{5}{|l|}{ Svalbard } \\
\hline Brandal & DS & $78^{\circ} 56^{\prime} 17.10^{\prime \prime} \mathrm{N} / 11^{\circ} 49^{\prime} 46.14^{\prime \prime} \mathrm{E}$ & $\mathrm{IVb}$ & Moss carpets \\
\hline Daerten & DS & $78^{\circ} 51^{\prime} 00.55^{\prime \prime} \mathrm{N} / 11^{\circ} 47^{\prime} 31.92^{\prime \prime} \mathrm{E}$ & III & Gentle brash predominance of lichens \\
\hline Geopol & SS & $78^{\circ} 56^{\prime} 58.38^{\prime \prime} \mathrm{N} / 11^{\circ} 28^{\prime} 35.64^{\prime \prime} \mathrm{E}$ & IVc & Permafrost polygon soils \\
\hline London Bloomstrand & DS & $78^{\circ} 57^{\prime} 46.14^{\prime \prime} \mathrm{N} / 12^{\circ} 04^{\prime} 52.26^{\prime \prime} \mathrm{E}$ & $\mathrm{IVa}$ & Diverse BSC coverage \\
\hline Zeppelin tower & DS & $78^{\circ} 55^{\prime} 16.80^{\prime \prime} \mathrm{N} / 11^{\circ} 56^{\prime} 52.32^{\prime \prime} \mathrm{E}$ & IVa & Extensive, diverse BSC coverage \\
\hline Ny-Ålesund station & DS & $78^{\circ} 55^{\prime} 26.33^{\prime \prime} \mathrm{N} / 11^{\circ} 55^{\prime} 23.84^{\prime \prime} \mathrm{E}$ & IVa & Extensive, diverse BSC coverage \\
\hline Bjørndalen & DS & $78^{\circ} 13^{\prime} 10.02^{\prime \prime} \mathrm{N} / 15^{\circ} 18^{\prime} 46.62^{\prime \prime} \mathrm{E}$ & $\mathrm{IVb}$ & Moss carpets \\
\hline Eindalen & DS & $78^{\circ} 10^{\prime} 47.05^{\prime \prime} \mathrm{N} / 15^{\circ} 43^{\prime} 06.01^{\prime \prime} \mathrm{E}$ & $\mathrm{IVb}$ & Moss carpets \\
\hline Eindalen entrance & DS & $78^{\circ} 11^{\prime} 10.13^{\prime \prime} \mathrm{N} / 15^{\circ} 45^{\prime} 37.51^{\prime \prime} \mathrm{E}$ & $\mathrm{IVa}$ & Extensive BSC coverage \\
\hline Breinosa, Gruve 7 & SS & $78^{\circ} 08^{\prime} 54.60^{\prime \prime} \mathrm{N} / 16^{\circ} 02^{\prime} 53.34^{\prime \prime} \mathrm{E}$ & II & Inactive scree: patchy BSCs \\
\hline \multicolumn{5}{|l|}{ Livingston Island } \\
\hline Plot 1 & SS & $62^{\circ} 39^{\prime} 56.20^{\prime \prime} \mathrm{S} / 60^{\circ} 23^{\prime} 49.50^{\prime \prime} \mathrm{W}$ & III & Hillock lichens, BSCs, few mosses \\
\hline Plot 2 & SS & $62^{\circ} 39^{\prime} 55.44^{\prime \prime} \mathrm{S} / 60^{\circ} 23^{\prime} 42.76^{\prime \prime} \mathrm{W}$ & $\mathrm{V} / \mathrm{IV}$ & Moss carpets/hillock lichens, BSCs \\
\hline Plot 3 & SS & $62^{\circ} 40^{\prime} 04.00^{\prime \prime} \mathrm{S} / 60^{\circ} 23^{\prime} 51.40^{\prime \prime} \mathrm{W}$ & IVa & Hillock lichens, BSCs, more mosses \\
\hline Plot 4 & SS & $62^{\circ} 40^{\prime} 06.00^{\prime \prime} \mathrm{S} / 60^{\circ} 23^{\prime} 28.70^{\prime \prime} \mathrm{W}$ & II & Inactive scree: patchy BSCs \\
\hline Plot 5 & SS & $62^{\circ} 40^{\prime} 02.20^{\prime \prime} \mathrm{S} / 60^{\circ} 23^{\prime} 38.70^{\prime \prime} \mathrm{W}$ & IVa & Hillock lichens, BSCs, mosses \\
\hline Plot 6 & SS & $62^{\circ} 39^{\prime} 39.40^{\prime \prime} \mathrm{S} / 60^{\circ} 22^{\prime} 46.40^{\prime \prime} \mathrm{W}$ & $\mathrm{IVb}$ & Less BSCs, maybe initiate stages \\
\hline
\end{tabular}

Soils are distinguished between $D S$ deeper soils and $S S$ skeletal soils as determined by observation and the MDS results

snow, another factor, such as meltwater, may contribute. Vincent et al. (2011) also describe these "snowflush communities," in the Canadian High Arctic, as allowing extensive development of cryptogamic crusts and inclusion of mosses.

In Livingston, chlorolichens are the dominant functional group compared to the mosses of Svalbard, which highlights the different types of communities found in Polar BSCs. The fruticose lichens, which dominate the rocky hillocks of Livingston, are much more suited to areas with very little soil and water accumulation. Rocky sites in Svalbard such as Geopol do not allow BSCs to develop to the stage where large fruticose lichens can dominate. This is due to the constant soil shifting by regular freeze thaw cycles that lead to the characteristic polygon circles.

The initial colonisation of cyanobacteria stabilising soil (Elster 2002), leading to a cyanobacterial crust, is considered a pioneering stage of BSC development (Turicchia et al. 2005; Yoshitake et al. 2010), which is shown in BSCs worldwide. However, in some habitats, cyanobacterial crusts can also contribute to a climax community, as seen in the Austrian Alps (Büdel et al. 2014) and as we presume in Svalbard, where sites are not dominated by scree or polygon soils.

The BSC community structures are particularly varied in Svalbard, much more than in Livingston, but this could simply be due to scale. The areas covered in Svalbard are much vaster and therefore have greater differences in environmental parameters that contribute to the structuring of the communities. However, Sancho et al. (1999) showed that the South bay area is very similar in vegetation composition to that described by Lindsay (1971) for the rest of Livingston Island and St. George Island. Although our study area is small, the previous research suggests that the community composition can be extrapolated from this area to a greater scale. Considering the differences in lichen species numbers, 110 around Juan Carlos I base, Livingston, and 211 for the Shetland Islands, compared to 600 for Svalbard, we may suppose that the Maritime Antarctic does not have the diversity of BSC species composition as we see in the Arctic. However, these lichen numbers are based on total numbers and not only those associated with BSCs. Although the present study focuses on functional groups to distinguish between vegetation types, considering species numbers is important to put into perspective the contrast in diversity between both Polar Regions.

The arrangement and distribution of BSC communities described are based on functional group; climatic attributes and soil properties were not used in the analysis as the data are only available on a large scale for all areas. Key species are demonstrated (Fig. 2), but complete species lists are not, they are, however, currently available in the literature. 
Functional group alone is a powerful tool in the description of BSCs. It is interesting to note that two Polar sites dominated by BSCs in their natural environments in some of the most pristine habitats on Earth were surveyed for the first time from a BSC perspective. Both sites are influenced by similar environmental conditions, have a history of glaciation, have polygon sorted soils due to freeze thaw action, and do not so far show great differences in soil properties. Nevertheless, the variations in functional group dominance and composition are vast.

\section{Outlook}

This paper has intended to provide, for the first time, a framework for outlining and understanding the difference in BSC composition in two Polar areas that have so far not been assigned a BSC status. Upcoming studies will assess the biodiversity, community composition, and physiology of the microalgae and cyanobacteria associated with the BSCs in these regions, and hence help to provide a complete evaluation and understanding of the structure and functioning of these important micro-ecosystems.

Acknowledgments The authors thank the crew at the AWIPEV base in Ny Ålesund, as well as those at Juan Carlos I in Livingston for assistance in the field work and technical equipment. The Spanish Antarctic committee also provided essential aid in travel to and from Livingston. Financing and logistical support of the research in $\mathrm{Ny}$ Ålesund and Livingston was kindly provided by the German Research Council in the framework of the Priority Programme "Antarctic Research” 1158 (DFG, KA899/23-1, BE1779/18-1, BÜ666/17-1).

Open Access This article is distributed under the terms of the Creative Commons Attribution 4.0 International License (http://crea tivecommons.org/licenses/by/4.0/), which permits unrestricted use, distribution, and reproduction in any medium, provided you give appropriate credit to the original author(s) and the source, provide a link to the Creative Commons license, and indicate if changes were made.

\section{References}

Arche A, López-Martínez J, Martínez de Pisón E (1992) Sedimentology of the Miers Bluff formation, Livingston Island, South Shetland Islands. In: Yoshida Y et al (eds) Recent progress in Antarctic Earth Science. Terra Scientific publishing, Tokyo, pp 357-362

Bañón M (1989) Observaciones meteorológicas de la Base Antártica "Juan Carlos I". Paralelo 37:25-32

Bañón M, Justel A, Velázquez D, Quesada A (2013) Regional weather survey on Byers Peninsula, Livingston Island, South Shetland Islands, Antarctica. Antarct Sci 25:146-156

Belnap J (2002) Nitrogen fixation in biological soil crusts from southeast Utah, USA. Biol Fert Soils 35:128-135

Belnap J (2003) Biological soil crusts in deserts: a short review of their role in soil fertility, stabilization, and water relations. Algol Stud 109:113-126
Belnap J, Lange OL (2003) Biological soil crusts: structure, function and management. Ecological studies 150. Springer, Berlin

Bengtsson SA (1999) Terrestrisk liv på Svalbard. Beskrivelse av mljöfoholdene og ökologiske forutsetninger. In: Norsk Polarinstitutt. Meddelelser 150:21-31

Bliss LC, Gold WG (1999) Vascular plant reproduction, establishment, and growth and the effects of cryptogamic crusts within a polar desert ecosystem, Devon Island, NWT, Canada. Can J Bot 77:623-636

Büdel B, Darienko T, Deutschewitz K, Dojani S, Friedl T, Mohr KI, Salisch M, Reisser W, Weber B (2009) Southern African biological soil crusts are ubiquitous and highly diverse in drylands, being restricted by rainfall frequency. Microb Ecol 57:229-247

Büdel B, Colesie C, Green TGA, Grube M, Lázaro Suau R, LoewenSchneider K, Maier S, Peer T, Pintado A, Raggio J, Ruprecht U, Sancho LG, Schroeter B, Türk R, Weber B, Wedin M, Westberg M, Williams L, Zheng L (2014) Improved appreciation of the functioning and importance of biological soil crusts in Europe: the Soil Crust International Project (SCIN). Biodivers Conserv 23:1639-1658

Castello M, Nimis R (1997) Diversity of lichens in Antarctica. In: Battaglia B, Valenica J, Walton DWH (eds) Antarctic communities: species, structure and survival. Cambridge University Press, Cambridge, pp 15-21

Colesie C, Gommeaux M, Green TGA, Büdel B (2013) Biological soil crusts in continental Antarctica: Garwood Valley, southern Victoria Land, and Diamond Hill, Darwin Mountains region. Antarct Sci 9:1-9

Colesie C, Green TGA, Haferkamp I, Büdel B (2014) Habitat stress initiates changes in composition, $\mathrm{CO}_{2}$ gas exchange and $\mathrm{C}$-allocation as life traits in biological soil crusts. ISME J 8:2104-2215

Cooper EJ (2011) Polar desert vegetation and plant recruitment in Murchisonfjord, Nordaustlandet, Svalbard. Geogr Ann A 93:243-252

Cooper EJ, Alsos IG, Hagen D, Smith FM, Coulson SJ, Hodkinson ID (2004) Plant recruitment in the High Arctic: Seed bank and seedling emergence on Svalbard. J Veg Sci 15:115-124

de los Ríos A, Raggio J, Pérez-Ortega S, Vivas M, Pintado A, Green TGA, Ascaso C, Sancho LG (2011) Anatomical, morphological and ecophysiological strategies in Placopsispycnotheca (lichenized fungi, Ascomycota) allowing rapid colonization of recently deglaciated soils. Flora 206:857-864

Dickson L (2000) Constraints to nitrogen fixation by cryptogamic crusts in a polar desert ecosystem, Devon, N.W.T., Canada. Arct Antarct Alp Res 32:40-45

Dugard P, Todman J, Staines H (2010) Approaching multivariate analysis, 2nd edn. A practical introduction, Routledge

Eldridge DJ, Rosentreter R (1999) Morphological groups: a framework for monitoring microphytic crusts in arid landscapes. J Arid Environ 41:11-25

Elster J (2002) Ecological classification of terrestrial algal communities of polar environment. In: Beyer L, Boelter M (eds) Geoecology of Antarctic ice-free coastal landscapes. Ecological studies 154. Springer, Berlin, pp 303-319

Elster J, Lukesová A, Svoboda J, Kopecky J, Kanda H (1999) Diversity and abundance of soil algae in the polar desert, Sverdrup Pass, central Ellesmere Island. Polar Record 35:231-254

Elvebakk A (1994) A Survey of Plant Associations and Alliances from Svalbard. J Veg Sci 5:791-802

Elvebakk A, Hertel H (1997) A catalogue of Svalbard lichens. In: Elvebakk A, Prestrud P (eds) A catalogue of Svalbard plants, fungi, algae, and cyanobacteria. Norsk Polarinstitutt Skrifter, Oslo, pp 271-359 
Gimingham CH, Lewis Smith RI (1970) Bryophyte and lichen communities in the Maritime Antarctic. In: Holdgate MW (ed) Antarctic Ecology 2. Academic Press, London, pp 752-785

Green TGA, Broady PA (2001) Biological soil crusts of Antarctica. In: Belnap J, Lange OL (eds) Biological soil crusts: structure, function and management. Springer, Berlin, pp 133-140

Haus NW, Wilhelm KR, Bockheim JG, Fournelle J, Miller M (2015) A case for chemical weathering in soils of Hurd Peninsula, Livingston Island, South Shetland Islands, Antarctica. Geoderma 263:185-194

Hodkinson ID, Coulson SJ, Webb NR, Coulson J (2003) Community assembly along proglacial chronosequences in the high Arctic: vegetation and soil development in north-west Svalbard. J Ecol 91:651-663

Johansen BE, Karlsen SR, Tømmervik H (2012) Vegetation mapping of Svalbard utilising Landsat TM/ETM+ data. Polar Rec 48:47-63

Jónsdóttir IS (2005) Terrestrial Ecosystems on Svalbard: heterogeneity, fragility and complexity from an Arctic island perspective. Biol Environ 105B:155-165

Lange OL, Kilian E, Ziegler H (1986) Water vapor uptake and photosynthesis of lichens: performance differences in species with green and blue-green algae as phycobionts. Oecologia 71:104-110

Levy EB, Madden EA (1933) The point method of pasture analysis. New Zealand J Agr 46:267-279

Lewis Smith RI (1972) Vegetation of the South Orkney Islands with particular reference to Signy Island. Br Antarct Surv Sci Rep 68:1-124

Lewis Smith RI (1984) Terrestrial plant biology of the sub-Antarctic and Antarctic. In: Laws RM (ed) Antarctic ecology 1. Academic Press, London, pp 61-162

Lewis Smith RI (1996) Terrestrial and freshwater biotic components of the Western Antarctic Peninsula. In: Ross RM, Hofmann EE, Quetin LB (eds) Foundations for ecological research West of the Antarctic Peninsula. American Geophysical Union, Washington D.C

Lewis Smith RI, Poncet S (1987) Deschampsia antarctica and Colobanthus quitensis in the Terra Firma Islands. Br Antarct Surv Bull 74:31-35

Lindsay DC (1971) Vegetation of the South Shetland Islands. Brit Antarct Surv B 25:59-83

Mann DH, Sletten RS, Ugolini FC (1986) Soil development at Kongsfjorden, Spitzbergen. Polar Res 4:1-16

Moura PA, Francelino MR, Schaefer CEGR, Simas FNB, de Mendonça BAF (2012) Distribution and characterization of soils and landform relationships in Byers Peninsula, Livingston Island, Maritime Antarctica. Geomorphology 155-156:45-54

Navas A, López-martínez J, Casas J, Machín J, José J, Serrano E, Cuchi J, Mink S (2008) Soil characteristics on varying lithological substrates in the south Shetland islands, maritime Antarctica. Geoderma 144:123-139

Ochyra R (1998) The Moss Flora of King George Island, Antarctica. Polish Academy of Sciences, W. Szafer Institute of Botany, Cracow

Ochyra R, Lewis Smith RI (1999) Meesia uliginosa Hedw. (Musci, Meesiaceae) in Antarctica. Cryptogamie Bryologie 20:5-10

Olech M (2002) Plant communities on King George Island. In: Beyer L, Bölter M (eds) Geoecology of Antarctic ice-free coastal landscapes. Springer, Berlin, pp 215-231

Otero XL, Fernández S, de Pablo Hernandez MA, Nizoli EC, Quesada A (2013) Plant communities as a key factor in biogeochemical processes involving micronutrients $(\mathrm{Fe}, \mathrm{Mn}, \mathrm{Co}$ and $\mathrm{Cu}$ ) in
Antarctic soils (Byers Peninsula, maritime Antarctica). Geoderma 195-196:145-154

Øvstedal DO, Lewis Smith RI (2001) Lichens of Antarctica and South Georgia, a guide to their Identification and Ecology. Studies in Polar Research. Cambridge University Press, Cambridge

$\emptyset$ vstedal DO, Tønsberg T, Elvebakk A (2011) The lichen flora of Svalbard. Sommerfeltia 33:3-393

Peer T, Türk R, Gruber JP, Tschaikner A (2010) Species composition and pedological characteristics of biological soil crusts in a high alpine ecosystem, Hohe Tauern, Austria. J Prot Mt Areas Res 2:23-30

Pietrasiak N, Johansen JR, LaDoux T, Graham RC (2011) Comparison of disturbance impacts to and spatial distribution of biological soil crusts in the Little San Bernardino Mountains of Joshua Tree National Park, California. West N Am Nat 71:539-552

Prach K, Košnar J, Klimešová J, Hais M (2010) High Arctic vegetation after 70 years: a repeated analysis from Svalbard. Polar Biol 33:635-639

Prach K, Klimešová J, Košnar J, Redčenko O, Hais M (2012) Variability of contemporary vegetation around Petuniabukta, central Spitsbergen. Pol Polar Res 33:383-394

Pushkareva E, Elster J (2013) Biodiversity and ecological classification of cryptogamic soil crusts in the vicinity of Petunia Bay, Svalbard. Czech Polar Reports 3:7-18

Sancho LG, Schulz F, Schroeter B, Kappen L (1999) Bryophyte and lichen flora of South Bay (Livingston Island: South Shetland Islands, Antarctica). Nova Hedwigia 68:301-338

Szymański W, Skiba M, Wojtuń B, Drewnik C (2015) Soil properties, micromorphology, and mineralogy of Cryosols from sorted and unsorted patterned grounds in the Hornsund area, SW Spitsbergen. Geoderma 253-254:1-11

Tredow JCF (1977) Soils of the polar landscape. Rutgers University Press, New Brunswick, p 638

Turicchia S, Ventura S, Schütte U, Soldati E, Zielke M, Solheim B (2005) Biodiversity of the cyanobacterial community in the foreland of the retreating glacier Midtre Lovènbreen, Spitsbergen, Svalbard. Algol Stud 117:427-440

Vanderpuye A, Arve E, Lennard N (2002) Plant communities along environmental gradients of high-arctic mires in Sassendalen, Svalbard. J Veg Sci 13:875-884

Vincent WF, Fortier D, Lévesque E, Boulanger-Lapointe N, Tremblay B, Sarrazin D, Antoniades D, Mueller DR (2011) Extreme ecosystems in the Canadian High Arctic: Ward Hunt Island and vicinity. Ecoscience 18:236-261

Wojtuń B, Samecka-Cymerman A, Kolon K, Kempers AJ, Skrzypek G (2013) Metals in some dominant vascular plants, mosses, lichens, algae, and the biological soil crust in various types of terrestrial tundra, SW Spitsbergen, Norway. Polar Biol 36:1799-1809

Yoshitake S, Uchida M, Koizumi H, Nakatsubo T (2007) Carbon and nitrogen limitation of soil microbial respiration in a High Arctic successional glacier foreland near Ny-Alesund, Svalbard. Polar Res 26:22-30

Yoshitake S, Uchida M, Koizumi H, Kanda H, Nakatsubo T (2010) Production of biological soil crusts in the early stage of primary succession on a High Arctic glacier foreland. New Phytol 186:451-460

Zheng LJ, Maier S, Grube M, Türk R, Gruber JP, Peer T (2014) Alpine biological soil crusts on the Hochtor (Grossglockner high alpine route, Hohe Tauern, Austria): soils, function and biodiversity. Acta ZooBot Austria 150(151):175-196 